\title{
Detection of neuropathy using a sudomotor test in type 2 diabetes [Corrigendum]
}

Gandhi and Rao. Degener Neurol Neuromuscul Dis. $2015 ; 5: 1-7$.

On page 2, the second sentence in the "SudoPath background" section is currently written: "The SudoPath is a patented system, and it uses the QSART method, by electrical stimulation of the postsympathetic cholinergic fibers and the switching of polarity, which induces microcirculation vasodilation and the release of chloride ions $\left(\mathrm{Cl}^{-}\right)$via the sweat ducts."

It should have been: "SudoPath uses the quantitative sudomotor test method, by electrical stimulation of the postsympathetic cholinergic fibers and the switching of voltage polarity, which induces microcirculation vasodilation and the release of sweat."

On page 3, the first sentence in the "How does the SudoPath work?" section is currently written: "The electronic box generates a low-voltage output (maximum 1.6 V) with a weak direct current (DC) current that is fed to the active electrode and then delivered to the contralateral electrode in two directions for each pathway."

It should have been: "The electronic box generates a constant low-voltage output (of $1.28 \mathrm{~V}$ ) with a weak direct current (DC) that is fed to the active electrode and then delivered to the contralateral electrode in two directions for each pathway."

On page 3, the "Conductance at the anode marker" section is currently written: "The change in polarity during the measurement at the anode increases the voltage, and the $\mathrm{Cl}^{-}$can be oxidized since the voltage is $>1.31 \mathrm{~V}$ and the anode is of opposite polarity. Water molecules and $\mathrm{Cl}^{-}$can be oxidized at the anode. ${ }^{17}$ The oxidation reaction at the anode is:

$$
\mathrm{H} 2 \mathrm{O}+\mathrm{Cl}^{-} \rightarrow(\mathrm{ClOH})+\left(\mathrm{H}^{+}\right)+\left(\mathrm{e}^{-}\right)
$$

Because the released sweat at the anode contain $\mathrm{Cl}^{-}$ions, we suggest the more probable assumption that the conductance measured at the anode will be related to the release of the $\mathrm{Cl}^{-}$; for this reason, we called the measured conductance at the anode "electrochemical skin response $\mathrm{Cl}^{-}\left(\mathrm{ESRCl}{ }^{-}\right)$" because at a voltage lower than $10 \mathrm{~V}$, the stratum corneum acts as a capacitor. ${ }^{19}$ The only way for the Chloride ions to exit and react with the plate electrode is through the sweat ducts. Therefore, $\mathrm{ESRCl}^{-}$could be a valid test of the sweat gland nerve density."

It should have been: "Further to expert review of the method of measurement of the SudoPath system, the assumption that there is a release of chloride ions at the anode has been reviewed. Although the voltage applied is thermodynamically sufficient to drive electrolysis, the rate is so slow that the voltage of the external source would have to be increased to that to make the process proceed in a reasonable time frame.

In addition, there is a competition between the negative ions at the positive electrodes. The chloride ions compete with the hydroxide ions to release electrons to the positive electrodes. As there is a very low concentration of chloride ions in the sweat $(0.2$ to $0.5 \%), \mathrm{OH}^{-}$ions are preferentially released at the positive electrode. The oxidation reactions at the anode are:

$$
\begin{aligned}
& 4 \mathrm{OH}^{-} \rightarrow 2 \mathrm{H} 2 \mathrm{O}+\mathrm{O} 2(\mathrm{~g})+4 \mathrm{e} \\
& 2 \mathrm{H} 2 \mathrm{O} \rightarrow \mathrm{O} 2(\mathrm{~g})+4 \mathrm{H}^{+}+4 \mathrm{e}^{-}
\end{aligned}
$$

This clarification does not affect the clinical evaluation or effectiveness and data analysis of the SudoPath based only on skin conductance measurements."
Degenerative Neurological and Neuromuscular Disease

\section{Publish your work in this journal}

Degenerative Neurological and Neuromuscular Disease is an international, peer-reviewed, open access journal focusing on research into degenerative neurological and neuromuscular disease, identification of therapeutic targets and the optimal use of preventative and integrated treatment interventions to achieve improved outcomes, enhanced

\section{Dovepress}

survival and quality of life for the patient. The manuscript management system is completely online and includes a very quick and fair peer-review system. Visit http://www.dovepress.com/testimonials.php to read real quotes from published authors.

Submit your manuscript here: http://www.dovepress.com/degenerative-neurological-and-neuromuscular-disease-journal

submit your manuscript | www.dovepress.com

Dovepress

http://dx.doi.org// 0.2147/DNND.S87215 